\title{
The Place of the Dopaminergic Agonists in the Treatment of Parkinson's Disease: the View from the Trenches
}

\author{
David B. King
}

\begin{abstract}
The use of the dopamine receptor agonists in Parkinson's disease has a compelling logic. These agents are supposed to act independently of the dying cells of the substantia nigra directly on the cells of the striatum. Early clinical trials in advanced disease were only mildly impressive. Later they were found to be beneficial in early disease but their effectiveness waned. Their ultimate failure may reflect the fact that the majority of current agents do not stimulate D1 and D2 receptors in a physiologic ratio. The drugs may act presynaptically and with the eventual loss of the anatomic relationships between nigra and striatum the drugs fail. There is, however, a rationale to their current use. When used along with L-Dopa in early disease the development of late-stage fluctuations are reduced with the same anti-parkinsonian benefits. Merging this concept with the demonstrated effect of selegiline in slowing the course of the disease, the current practice of triple therapy with selegiline, L-Dopa and a dopamine receptor agonist emerges.

RÉSUMÉ: Place des agonistes dopaminergiques dans le traitement de la maladie de Parkinson: vue des tranchées. L'utilisation des agonistes dopaminergiques dans la maladie de Parkinson est d'une logique irrésistible. Ces agents sont supposés agir indépendamment des cellules en voie de disparition de la substance noire, directement sue les cellules du striatum. Les premiers essais cliniques chez des patients en phase avancée de la maladie étaient peu impressionnants. Ces agents ont ensuite été reconnus efficaces au début de la maladie, mais on observait un déclin du bénéfice avec le temps. Leur échec peut refléter le fait que la majorité des agents actuels ne stimule pas les récepteurs D1 et D2 selon une proportion physiologique. Ces agents peuvent agir au niveau présynaptique et, avec la perte éventuelle des relations anatomiques entre la substance noire et le striatum, l'effet est perdu. Il existe cependant une justification à leur utilisation actuelle. Quand ils sont utilisés avec la l-dopa au début de la maladie, l'apparition de fluctuations en phase tardive est réduite tout en conservant les mêmes bénéfices anti-parkinsoniens. En joignant ce concept à l'effet prouvé de la sélégiline de ralentir la progression de la maladie, la pratique actuelle d'une triple thérapie au moyen de la sélégiline, la l-dopa et un agoniste dopaminergique voit le jour.
\end{abstract}

Can.J. Neurol. Sci. 1992; 19: 156-159

\section{The Neurologists' Sabre}

The practicing neurologist may be likened to the Light Brigade at Balaclava, battered front and sides by the cannons of science and statistics. While academic armies clash amid the merciless barrage of advanced chemistry, he must wield his pharmacologic sabre to simpler trumpets. He must hold the thin line between theory and practice, between fact and speculation.

This paper will briefly review the current status of dopamine receptor agonists in the treatment of Parkinson's disease and argue, that despite current research efforts to find the ultimate agonist, the Holy Grail of parkinsonism, that they will always be little more than stop gap treatment with short term advantages.

\section{The Rise and Fall of the Dopaminergic Agonists}

In Parkinson's disease, agents acting directly on the postsynaptic dopamine receptor, bypassing the dying cells of the sub- stantia nigra, independent of the metabolic processes necessary to transform L-Dopa to dopamine, promised much. In the event, they lacked the efficacy of L-Dopa. They had minimal benefits in advanced disease and lost their effectiveness in early disease.

Dopamine analogues were first introduced in late Parkinson's disease when L-Dopa was already failing. They performed poorly, though some $50 \%$ of patients experienced a modicum of benefit. As doses rose so did side-effects. The fluctuating parkinsonian was transformed into a mobile dement with postural hypotension and hallucinations, he lacked the vocabulary to explain. This was not a propitious beginning. Lieberman, et al.,' in an early study added bromocriptine, a dopamine receptor agonist, to a carbidopa-levodopa regime. Out of fourteen patients four showed no benefit and nine improved only one point on the Hoehn and Yahr disability scale. The same author ${ }^{2}$ reviewed seven studies comprising 367 patients. These studies examined the addition of high-dose 
bromocriptine to a stable levodopa regime in advanced fluctuating parkinsonism. Though they demonstrated an improvement in 58\% of the patients, $31 \%$ experienced side effects. Rinne ${ }^{3}$ documented bromocriptine's side effects in a five year study. About $13 \%$ of his patients experienced nausea and vomiting. Eleven per cent complained of chest pain and shortness of breath while 7\% became confused and hallucinated. Postural hypotension complicated the course of an additional $1 \%$.

When bromocriptine is used in early disease as the first and exclusive treatment its benefits are seen to wane with time. At a dose of $40 \mathrm{mg} /$ day there was a $28 \%$ improvement in functioning which fell off to $12 \%$ by the fifth year of treatment. ${ }^{3}$

The logic of their use rather than the results saved the agonists from oblivion. New strategies and new agents hinted at a more propitious future. Perhaps we have now found their proper niche, though not the proper drug.

The reasons for dopaminergic failure are far from clear. It may be that the two types of dopamine receptors, D-1 and D-2, are stimulated in an inappropriate ratio. L-Dopa stimulates D2 twenty times more potently than DI. Bromocriptine stimulates only D2 and is a partial antagonist at D1. ${ }^{4}$ Pergolide stimulates both, but D1 only slightly. ${ }^{5}$ Apomorphine's spectrum more closely approximates that of dopamine. PHNO has no effect on D1 receptors. Lisuride has potent action at D2 and some action at DI (Table 1). ${ }^{6}$ The search continues for the ideal dopamine analogue.

Regardless of the ratio of D1 to D2 stimulation it is likely that topographical relationships are vital; in the end we will be slaves to anatomy. Studies by Korf et al. ${ }^{7}$ and Weterink ${ }^{8}$ in the mid- to late-seventies demonstrated that lesions placed in the nigrostriatal pathway resulted in a dramatic increase of DOPAC and HVA, suggesting a degree of lateral inhibition among nigral cells. As one might image that there is a high degree of redundancy in this neuronal system. It may then suffer considerable neuronal fallout before its anatomical and functional integrity is lost.

A variety of papers have demonstrated a topographical projection of nigra to striatum and striatum to nigra.-12 One presumes that these projected homunculi have some importance in the functioning of the striatonigral system.

One can not escape the possibility that the analogues work by blocking the D2 receptors presynaptically in a dose-dependent fashion. The neuron, not sensing the amount of dopamine released, produces more dopamine with some amelioration of the syndrome. In time the loss of cells within the substantia nigra reaches critical proportions and no amount of stimulation of the few ill cells that remain is sufficient to cause them to perform their function. The patient declines into end-stage immobility.

Table 1: Relative Actions of Dopamine and the Dopamine Agonists on D1 and D2 Receptors

\begin{tabular}{lll}
\hline \hline & D1 & D2 \\
\hline Dopamine & ++ & ++++ \\
Bromocriptine & - & +++ \\
Pergolide & + & +++ \\
Apomorphine & ++ & +++ \\
PHNO & & +++ \\
Lisuride & + & ++++ \\
\hline
\end{tabular}

The value of all the research into dopamine analogues is critically dependent on whether they work pre- or postsynaptically, and on whether they work independently of the loss of anatomic integrity.

\section{The Rationale for the Dopamine Receptor Agonists}

Despite misgivings about the long term effectiveness of the analogues, there are three pieces of evidence that justify their current use.

In a very recent paper Rinne ${ }^{13}$ studied 95 patients with idiopathic Parkinson's disease. He divided them into three groups based on treatment. Group I was managed with L-Dopa, selegiline and the dopamine analogue, lisuride; group 2 with L-Dopa and lisuride and group 3 with L-Dopa alone. He followed them for three years and demonstrated that all showed an initial functional improvement of around $60 \%$. As time passed, medication effectiveness was lost so that by three years the average improvement in all three groups had dropped to about $40 \%$. The interesting point was that the dopamine analogue and selegiline reduced the amount of L-Dopa for the same amount of improvement. Perhaps in consequence the percentage of patients who showed fluctuations of performance and dyskinesias was significantly less in groups 1 and 2 . At the end of three years, $42 \%$ of group 3 showed wearing-off compared to $7 \%$ of groups 1 and 2. The effect of dyskinesias was even more impressive. Sixty-two per cent of group 1 showed dyskinesias compared to $7 \%$ in group 2 and $4 \%$ in group 1.

L-Dopa and its analogues may work better tonically than phasically. It may be that the late evils of L-Dopa, fluctuating performance and dyskinesias, result from phasic rather than continuous dosing. It is well documented that motor response fluctuations can be reduced or eliminated by maintaining stable plasma levodopa concentrations through continuous intravenous infusions. ${ }^{14}$ In early disease the fluctuations may still exist, but are less apparent, as the off periods are less severe. The long half-life of drugs like pergolide ( 12 hours) and bromocriptine ( 3 hours) make them attractive in this context. Current strategies with the use of long-acting L-Dopa preparations are based on this assumption. The normal physiologic function of the striatum is dependent on a tonic input from the substantia nigra, superimposed on which there is phasic activity in response to motor demands. It would seem rational to administer our pharmacology in the same manner as the basal ganglia function (Table 2).

No one has convincingly shown that Parkinson's disease advances more rapidly when Sinemet is used. The late L-Dopa syndrome, the nightmare of the practicing neurologist, may reflect the pulsatile use of the agent as much as its use at all. It may also simply represent the best symptomatic agent that we have, L-Dopa, acting on a dwindling neuronal population.

The recent demonstration ${ }^{15}$ that the anti-oxidant, selegiline, slows the progress of the disease, tends to confirm the free radical theory of substantia nigra destruction, though other explanations for the results of this study are clearly possible. In the hidden recesses of the substantia nigra silent assassins strike and the pigmented cells die at their hands. Is L-Dopa their accomplice?

The free radical theory of substantia nigra destruction favors the use of dopamine receptor agonists. Their metabolism does not result in the production of hydrogen peroxide or other products capable of generating free radicals. 


\section{Future Campaigns}

The future holds development of further members of the dopamine receptor agonist family. The search is on for the agent offering dynamic stimulation of dopamine receptors in their most favorable ratios.

Some, such as PHNO, offer the possibility of novel delivery systems, such as transdermally. This will allow more continuous stimulation of the striatum. Others may be implanted in striatum and pallidum with synthetic perforated implants. The ultimate aim is to bathe the striatum continuously in dopaminergics that act in an appropriate ratio D2:D1. The problem, as already indicated, may be more complex with the requirement for anatomic integrity. Perhaps the elusive ratio may yet be found which will stimulate anatomically discreet areas of the basal ganglia, D2 receptors in the striatum, the input to the basal ganglia and DI receptors of pallidum and substantia nigra pars reticulata, the output of the system. This dual and anatomically distinct separation of D1 and D2 receptors may be the key which opens the parkinsonian mystery.

Recent work has examined a variety of dopaminergic analogues acting with varying degrees of potency on D1 or D2 receptors (Table 3). All of these are short term studies save Cedarbaum's which showed that tolerance developed to the effects of $\mathrm{PHNO}^{16}$. This strengthens the argument that given the passage of time all these agents may be expected to fail as the disease advances and the nigra dies.

\section{The Neurologists' Order of Battle}

What then is the clinician to do when faced with the tremulous and bradykinetic patient sitting on the other side of his desk? No one disagrees that a decision to treat should be based on the patient's loss of function rather than cosmetics. All treatment should be reserved until needed and when needed tailored

Table 2: Approximate Half-Lives of L-Dopa and Other Dopamine Receptor Agonists

\begin{tabular}{ll}
\hline \hline Agent & Half-life \\
\hline L-Dopa & 1.5 hours \\
Bromocriptine & 3 hours \\
Pergolide & 12 hours \\
Lisuride & 1.5 hours \\
\hline
\end{tabular}

Table 3: Recent Papers Dealing with the Effectiveness of New Dopamine Agonists.

\begin{tabular}{llllc}
\hline \hline Agonist & Receptor & Model & Result & Reference \\
\hline PHNO & D2 & Human & tolerance & 16 \\
PHNO & D2 & Animal & effective & 17 \\
$+3 P P P$ & D2 & Animal & effective & 17 \\
SKF-38393 & D1 & Animal & ineffective & 17 \\
PHNO & D2 & Human & effective & 18 \\
CV 205-502 & D1+D2 & Human & effective & 19 \\
CY 208-243 & D1 & Human & effective & 20 \\
CQP 201-403 & D1+D2 & Human & effective & 21 \\
\hline
\end{tabular}

to the patient. The watch maker may need earlier treatment than the woodsman.

We have come full-circle. Dopamine analogs were to succeed when L-Dopa failed. They now frequently commence the action with L-Dopa added in close support. What has emerged for the clinician is the concept of the triple therapy for Parkinson's disease: L-Dopa, an analogue and selegiline.

\section{ConClusion}

The solution to the parkinsonian problem remains elusive despite rapid strides since the introduction of L-Dopa. We need the cause. However, we can still practice secure in the knowledge that we have made a meaningful contribution to the lives of our patients who suffer this disabling disease.

\section{REFERENCES}

1. Lieberman AN, Zolfaghari M, Bol D, et al. The anti-parkinsonian efficacy of bromocriptine. Neurology 1976; 26: 405.

2. Lieberman AN, Gopinathan G, Nelphytides A, et al. Dopamine agonists in Parkinson's disease. In: Stern G, ed. Parkinson's Disease. Baltimore: John Hopkins, 1990: 509-535.

3. Rinne UK. Combined bromocriptine - levadopa therapy early in Parkinson's disease. Neurology 1985; 35: 1196-1198.

4. Schran HF, Bhuta SI, Schwartz HJ. The pharmacokinetics of bromocriptine in man. $/ n$ : Goldstein M, ed. Ergot Compounds and Brain Function: Neuroendocrine and Neuropsychiatric Aspects. New York: Raven Press, 1980: 125-139.

5. Goldstein M, Lew JY, Sauter A, et al. The affinities of ergot compounds for dopamine agonist and dopamine antagonist receptor sites. In: Goldstein M, ed. Ergot Compounds and Brain Functions: Neuroendocrine and Neuropsychiatric Aspects. New York: Raven Press, 1980: 75-82.

6. Horowski R. Differences in the dopaminergic effects of the ergot derivatives bromocryptine, lisuride and D-LSD as compared with apomorphine. Eur J Pharmacol 1978; 51: 157-166.

7. Korf J, van der Heyden JAM, Westerink BHC. Coordination of dopaminergic processes in the striatum and the role of presynaptic lateral inhibition. In: Cols AR, Lohman AHM, van den Bercken JHL, eds. Psychobiology of Striatum. Amsterdam: Elsevier, 1977: 51-59.

8. Westerink BHC. Regional dopamine metabolism in the rat brain. Thesis, University of Groningen, 1977.

9. Bjorklund $A$, Lindvall $\mathrm{O}$. Dopamine-containing systems in the CNS. In: Bjorklund A, Hokfelt T, eds. Classical Transmitters in the CNS, Part 1. Handbook of Chemical Neuroanatomy 2, London: Elsevier, 1984: 55-122.

10. Moore RY, Bloom FE. Central catecholamine neuron systems: anatomy and physiology of the dopamine systems. Ann Rev Neurosci 1978; 1: 129.

11. Nauta WJH, Domesick VB. Afferent and efferent relationships of the basal ganglia. In: Evered D, O'Connor M, eds. Functions of the Basal Ganglia, CIBA Foundation Symposium 107. London: Pittman, 1984: 3-23.

12. Szabo J. Striatonigral and nigrostriatal connections. Appl Neurophysiol 1979; $42: 9$.

13. Rinne UK. Combination of a dopamine agonist, M.A.O-D inhibitor and levadopa - a new strategy in the treatment of early Parkinson's disease. Acta Neurol Scand 1989; 126: 165-169.

14. Quinn N, Parkes JD, Marsden CD. Control of on/off phenomenon by continuous intravenous infusion of levodopa. Neurology 1984; 34: 1131-1136.

15. The Parkinson study group: effect of deprenyl on the progression of disability in early Parkinson's disease. N Engl J Med 1989; 321: 1364-1371.

16. Cedarbaum JM, Clark M, Toy LH, et al. Sustained release PHNO in the treatment of Parkinson's disease: evidence for tolerance to a selective D2-receptor agonist administered as a long-acting formulation. Mov Disord 1990; 5: 298-303. 
17. Close SP, Elliott DJ, Hayes AG, et al. Effects of classical and novel agents in an MPTP-induced reversible model of Parkinson's disease. Psychopharmacology 1990; 102(3): 195-300.

18. Marsden CD, Coleman RJ, Quinn NP, et al. Nasogastric and intravenous infusions of PHNO in Parkinson's disease. J Neurol Neurosurg Psychiatry 1990; 53(2): 102-105.

19. Olanow CW, Werner EG, Gauger LL. CV 205-502: Safety, tolerance to and efficacy of increasing doses in patients with Parkinson's disease in a double-blind placebo cross-over study. Clin Neuropharmacol 1989; 12(6): 490-497.
20. Temlett JA, Quinn NP, Jenner PG, et al. Antiparkinsonian activity of CY 208-243, a partial D-1 dopamine receptor agonist, in MPTP-treated marmosets and patients with Parkinson's disease. Mov Disord 1989; 4: 261-265.

21. Pfeiffer RF, Herrera LH, Glaeske CS, et al. CQP 201-403 in Parkinson's disease: an open-label pilot study. Mov Disord 1989; 4: $278-281$. 